\title{
FAKTOR RESIKO YANG BERHUBUNGAN DENGAN KEJADIAN PNEUMONIA PADA ANAK BALITA USIA 1-5 TAHUN DI BLUD RSUD dr. DORIS SYLVANUS PALANGKA RAYA.
}

\section{Risk Factors Associated With The Event Of Pneumonia In Children In 1-5 Years Of Age In Blud Rsud Dr. Doris Sylvanus Palangka Raya.}

\author{
Supriandi, ${ }^{1}$, H. Barto Mansyah ${ }^{2}$ \\ POLTEKKES KEMENKES PALANGKARAYA \\ (Uzanksupriandi80@yahoo.com)
}

\begin{abstract}
ABSTRAK
Latar Belakang : Pneumonia adalah penyebab utama kematian anak-anak di seluruh dunia, Pneumonia diperkirakan membunuh sekitar 1,6 juta anak usia dibawah lima tahun (balita) dalam setiap tahunnya. Dampak pneumonia dapat menimbulkan komplikasi akut berupa supurasi (abses paru maupun empyem thoracis) bila tidak ditangani dengan tepat maka tidak jarang penderita akan meninggal pada akhir minggu kedua yang terhitung sejak pasien menderita pneumonia.

Tujuan Penelitian : untuk mengetahui Faktor Resiko yang berhubungan dengan kejadian Pneumonia pada anak balita usia 1-5 tahun di BLUD RSUD dr. Doris Sylvanus Palangka Raya.

Metode : Penelitian ini menggunakan metode analitik observasional dengan pendekatan cross sectional. Populasi penelitian ini adalah adalah seluruh pasien balita rawat jalan yang terdiagnosis menderita pneumonia Periode tahun 2014 dan 2015 di BLUD RSUD dr. Doris Sylvanus Palangka Raya, yaitu sebanyak 325 kasus. Subyek penelitian ini yaitu balita penderita pneumonia di BLUD RSUD dr. Doris Sylvanus Palangka Raya yang berjumlah 73 anak. Alat pengumpulan data yang digunakan yaitu pengumpulan data primer dan sekunder.

Hasil : p value pada variabel usia anak sebesar 0,016, riwayat pendidikan ibu sebesar 0,047 , riwayat menyusui sebesar 0,002 , riwayat imunisasi dasar sebesar 0,036 yang mana $\mathrm{p}$ value $<\alpha(0,05)$ sehingga dapat disimpulkan bahwa terdapat hubungan yang signifikan terhadap factor resiko kejadian Pneumonia sedangkan pada faktor berat badan lahir sebesar 0,899, jenis keamin sebesar 0,831dan status gizi sebesar 0,840 yang mana bertolak belakang dengan rumus $\mathrm{p}$ value sehingga dapat disimpulkan bahwa tidak ada hubungan yang signifikan terhadap faktor resiko kejadian Pneumonia.

Simpulan: Terdapat hubungan yang signifikan antara usia anak, riwayat pendidikan ibu, riwayat menyusui, riwayat imunisasi dasar terhadap factor resiko kejadian Pneumonia sedangkan pada faktor berat badan lahir, jenis keamin dan status gizi tidak ada hubungan yang signifikan terhadap faktor resiko kejadian Pneumonia
\end{abstract}

Kata kunci: Faktor Resiko, Pneumonia, Balita. 
Avicenna Journal of Health Research. Vol 1 No 2. Oktober 2018 (54-64)

\begin{abstract}
Background: The number of breastfeeding mothers who properly storing breast milk in Indonesia is still relatively low (18.7\%). This is because the knowledge of breastfeeding mothers about the importance of breastfeeding with the correct understanding of breastfeeding and how to milk and to store breast milk still insufficient.
\end{abstract}

The purpose of this study : to determine the relationship of knowledge and attitude of breastfeeding mothers about how to milk and store breastmilk in Posyandu Anggrek Sanggrahan Joho Sukoharjo in the year of 2017 ".

Method: This research use analytical survey method with cross sectional approach. The population of this study was all breastfeeding mothers in Posyandu Anggrek Sanggrahan Joho Sukoharjo which amounted to 38 people. This study did not use the sample but used the study subjects because all populations were taken for study. The data collection tool was closed questionnaire with Guttman scale.

Result: The knowledge of breastfeeding mothers about how to milk and store breastmilk majority were in enough and less category that each 12 people (36.4\%). The attitude of breastfeeding mothers about how to milk and store breastmilk majority were in good category, 16 people (48.5\%). There was a relationship between knowledge and attitude of breastfeeding mother about how to milk and store breast milk with correlation of Kendall's tau 0,406 at significance level 0,05 and got value of $Z_{\text {count }}=3,32>Z_{\text {table }}=1,96$.

Conclusion: There is a relationship between knowledge and attitude of breastfeeding mother about how to milk and store breast milk in Posyandu Anggrek Sanggrahan Joho Sukoharjo in the year of 2017.

Keywords: Knowledge, Attitude, Breastfeeding Mother, How to milk and to store breastmilk

\title{
PENDAHULUAN
}

Pneumonia adalah penyebab utama kematian anak-anak di seluruh dunia, Pneumonia diperkirakan membunuh sekitar 1,6 juta anak usia dibawah lima tahun (balita) dalam setiap tahunnya, melebihi dari Acquired Immunodeficiency Syndroma (AIDS), malaria dan Tuberculosis (TB) (WHO, 2010). Pneumonia dapat disebabkan karena virus, bakteri maupun jamur. Bayi dan Balita merupakan populasi yang paling rentan terkena Pneumonia dan kondisi tersebut umumnya terjadi pada balita dengan gizi kurang dan kondisi lingkungan yang tidak sehat. Pneumonia sebagai pembunuh utama anak usia 5 tahun (Balita) di dunia, lebih banyak jika dibandingkn dengan penyakit lain seperti AIDS, Malaria dan Campak. Didunia dari 9 juta kematian balita, 2 juta balita meninggal setiap tahun akibat pneumonia (Kemenkes RI, 2012).

Faktor resiko yang meningkatkan kejadian pneumonia balita, meliputi faktor intrinsik, ekstrinsik dan prilaku. Faktor intrinsik berupa umur, status imunisasi, status gizi, pemberian vitamin A dan pemberian Air Susu Ibu (ASI). Faktor 
ekstrinsik berupa lingkungan rumah yang terdiri dari komponen rumah yang menunjang terciptanya rumah yang sehat, seperti dinding, lantai, ventilasi, pencahayaan alami dan kepadatan penghuni (Depkes RI, 2009).

Di Indonesia angka kematian balita (AKABA) pada tahun 2007 mencapai 44/1000 kelahiran hidup, dan mengalami penurunan pada tahun 2012 sebesar 40/1000 kelahiran hidup, kemudian pada tahun 2013 mengalami penurunan lagi menjadi 23/1000 kelahiran hidup dan terjadi peningkatan pada tahun 2014 yaitu sebesar 32/1000 kelahiran hidup. Riset Kesehatan Dasar (2007) mengungkapkan bahwa pneumonia merupakan penyebab terbesar kedua kematian bayi di Indonesia $(15,5 \%)$ setelah diare $(25,2 \%)$. Penumonia balita di Indonesia meningkat dari 7,6\% pada tahun 2002 menjadi 11,2\% pada tahun 2007 serta menempati urutan 10 besar penyakit rawat inap di Rumah Sakit tahun 2010 dengan case fatality rate (CFR) 7,60\% (Kemenkes, 2012). Pneumonia merupakan penyebab kematian nomor dua pada balita $(12,2 \%)$, setelah diare $(17,2 \%)$. Angka cakupan kejadian pneumonia pada balita tidak mengalami perkembangan berarti yaitu sekitar antara 20\%$30 \%$. Angka kematian akibat pneumonia pada baita sebesar $0,08 \%$, lebih rendah dibandingkan dengan tahun 2013 yang sebesar 1,19\% (Kemenkes RI, 2014).

Angka kematian balita (AKABA) di Provinsi Kalimantan Tengah pada tahun 2013 sebesar 56/1000 kelahiran hidup, angka tersebut meningkat jika dibandingkan dengan tahun 2012 sebesar 45/1000 kelahiran hidup (Dinkes. Provinsi Kalteng, 2012, 2013). Angka kematian balita (AKABA) di kota Palangka Raya tahun 2014 sebesar 0,73/1000 kelahiran hidup, menurun jika dibandingkan dengan tahun 2013 mencapai 14,6/1000 kelahiran hidup, tahun 2012 tercatat 10,7/1000 kelahiran hidup, dan pada tahun 2011 mencapai 11,39/1000 kelahiran hidup. Penyebab kematian balita pada tahun 2013 di Kota Palangka Raya adalah akibat infeksi, penyakit menular, kecelakaan dan lainlain (Dinkes Kota Palangka Raya, 2014). Jumlah penderita pneumonia Balita yang ditemukan dan ditangani pada tahun 2013 sebanyak 681 kasus $(2,86 \%)$ lebih rendah bila dibandingkan dengan tahun 2012 sebanyak $771(3,55 \%)$ dan pada tahun 2014 cakupan penemuan pneumonia balita yang ditemukan dan diobati sesuai standar lebih rendah daripada tahun 2012 dan 2013, yaitu sebesar 462 kasus (1,9\%) masih rendah dan dibawah target 10\% (Dinkes Provinsi Kalimantan Tengah, 2013, 2014).

Berdasarkan data yang diperoleh dari buku register di Ruang Klinik Anak BLUD RSUD dr. Doris Sylvanus Palangka Raya pada tahun 2015 penderita pneumonia pada balita sebanyak 122 kasus $(2,6 \%)$ dari 4.627 kunjungan dan jumlah tersebut sedikit menurun dibandingkan tahun 2014 sebanyak 203 kasus $(3,20 \%)$ dari 6.343 kunjungan (Register Klinik Anak BLUD RSUD dr. Doris Sylvanus Palangka Raya, 2014, 2015).

Berdasarkan uraian di atas, maka peneliti tertarik untuk mengetahui " Faktor Resiko yang berhubungan dengan kejadian Pneumonia pada anak balita usia 1-5 tahun di BLUD RSUD dr. Doris Sylvanus Palangka Raya”. 


\section{METODE PENELITIAN}

Penelitian ini merupakan penelitian analitik observasional dengan pendekatan cross sectional. Populasi penelitian ini adalah adalah seluruh pasien balita rawat jalan yang terdiagnosis menderita pneumonia Periode tahun 2014 dan 2015 di BLUD RSUD dr. Doris Sylvanus Palangka Raya, yaitu sebanyak 325 kasus. Subyek penelitian ini yaitu balita penderita pneumonia di BLUD RSUD dr. Doris Sylvanus Palangka Raya yang berjumlah 73 anak.

Pada penelitian ini menggunakan alat pengumpul data berupa kuesioner, jenis kuesioner dalam penelitian ini adalah kuesioner tertutup dengan skala Guttman. Metode pengumpulan data yang digunakan adalah pengumpulan data primer dan sekunder. Dalam penelitian ini pengumpulan data primer dilakukan dengan membagikan kuesioner secara langsung kepada ibu menyusui, sedangkan pengumpulan data sekunder berupa format isian dan alat tulis untuk mencatat data dari buku register dan rekam medik di Klinik Anak BLUD RSUD dr. Doris Sylvanus Palangka Raya. Analisa data dalam penelitian ini menggunakan analisis univariat.

\section{HASIL DAN PEMBAHASAN}

Tabel 1 Distribusi Frekuensi Kejadian Pneumonia, usia anak, jenis kelamin, riwayat berat badan lahir, status gizi, pendidikan ibu, riwayat pemberian Asi Ekslusif dan riwayat imunisasi terhadap Kejadian Penumonia di BLUD RSUD dr. Doris Sylvanus Palangka Raya.

\begin{tabular}{lclcc}
\hline \multicolumn{1}{c}{ Variabel } & n & \multicolumn{1}{c}{ Kriteria } & Frekuensi & Persentase (\%) \\
\hline Penumonia & 100 & Pneumonia Lobaris & 34 & 34 \\
& & Pneumonia Lobularis & 48 & 48 \\
& & Pneumonia interstitial & 18 & 18 \\
\hline Usia Anak & 100 & $1-3$ tahun & 66 & 66 \\
& & $4-5$ tahun & 34 & 34 \\
\hline Jenis Kelamin & 100 & Laki-laki & 44 & 44 \\
& & Perempuan & 56 & 56 \\
\hline Riwayat Berat Badan Lahir & \multirow{2}{*}{100} & $<2500$ gram & 28 & 28 \\
& & 2500-4000 gram & 60 & 60 \\
& & $>4000$ gram & 12 & 12 \\
\hline Status Gizi & \multirow{2}{*}{100} & Gizi Baik & 86 & 86 \\
& & Gizi Kurang & 13 & 13 \\
& & Gizi Buruk & 1 & 1 \\
\hline Pendidikan Ibu & 100 & Pendidikan Tinggi & 32 & 32 \\
& & Pendidikan Rendah & 68 & 68 \\
\hline Riwayat Pemberian Asi & \multirow{2}{*}{100} & Ya & 29 & 29 \\
Ekslusif & Tidak & 71 & 71 \\
\hline Riwayat Imunisasi Dasar & 100 & Lengkap & 59 & 59 \\
& & Tidak Lengkap & 41 & 41 \\
\hline
\end{tabular}


Berdasarkan tabel distribusi frekuensi pada tabel 1, terlihat bahwa persentase kasus Pneumonia terbesar adalah Penumonia Lobularis (Bronkopneumonia), yaitu sebanyak 48\%. Kemudian pada variabel usia anak kasus pneumonia tertinggi terjadi pada anak usia 1-3 tahun, yaitu sebesar 66\%. Variabel Jenis Kelamin kasus pneumonia tertinggi terjadi pada anak berjenis kelamin perempuan sebanyak $56 \%$. Kemudian pada riwayat berat badan lahir tertinggi pada bayi yaitu sebanyak $60 \%$. Pada status gizi anak yang tertinggi yaitu gizi baik sebanyak $86 \%$. Pada variabel pendidikan ibu, kasus pneumonia pada anak terbesar terjadi pada ibu dengan pendidikan rendah, yaitu sebesar $68 \%$. Kemudian kasus pneumonia terjadi pada anak yang tidak mendapatkan Asi Ekslusif, yaitu sebanyak 71\%. Pada variabel Riwayat imunisasi sebanyak 59\% kasus pneumonia mempunyai riwayat imunisasi dasar lengkap.

Tabel 2 Faktor Resiko Kejadian Pneumonia Pada Anak Balita Usia 1-5 tahun di BLUD RSUD dr. Doris Sylvanus Palangka Raya.

\begin{tabular}{|c|c|c|c|c|c|c|c|c|c|}
\hline \multirow{3}{*}{ No } & \multirow{3}{*}{ Variabel } & \multirow{3}{*}{ Kriteria } & \multicolumn{6}{|c|}{ Pneumonia } & \multirow{3}{*}{ p value } \\
\hline & & & \multicolumn{2}{|c|}{$\begin{array}{c}\text { Penumonia } \\
\text { Lobaris }\end{array}$} & \multicolumn{2}{|c|}{$\begin{array}{c}\text { Pneumonia } \\
\text { Lobularis }\end{array}$} & \multicolumn{2}{|c|}{$\begin{array}{l}\text { Pneumonia } \\
\text { interstitial }\end{array}$} & \\
\hline & & & $\mathbf{n}$ & $\%$ & $\mathbf{N}$ & $\%$ & $\mathbf{n}$ & $\%$ & \\
\hline \multirow[t]{2}{*}{1} & Usia Anak & 1-3 tahun & 17 & 25,8 & 33 & 31,7 & 16 & 24,2 & $0,016^{*}$ \\
\hline & & 4-5 tahun & 17 & 50 & 15 & 44,1 & 2 & 5,9 & \\
\hline \multirow[t]{2}{*}{2} & Jenis Kelamin & Laki-laki & 15 & 34,1 & 20 & 45,5 & 9 & 20,5 & 0,831 \\
\hline & & Perempuan & 19 & 33,9 & 28 & 50 & 9 & 16,1 & \\
\hline \multirow[t]{3}{*}{3} & Riwayat Berat & $<2500$ gram & 13 & 46,4 & 11 & 39,3 & 4 & 14,3 & 0,899 \\
\hline & Badan Lahir & $2500-4000$ gram & 20 & 33,3 & 28 & 46,7 & 12 & 20 & \\
\hline & & $>4000$ gram & 1 & 8,3 & 9 & 75 & 2 & 16,7 & \\
\hline \multirow[t]{3}{*}{4} & Status Gizi & Gizi Baik & 29 & 37,7 & 33 & 42,9 & 15 & 19,5 & 0,840 \\
\hline & & Gizi Kurang & 5 & 22,7 & 14 & 63,6 & 3 & 13,6 & \\
\hline & & Gizi Buruk & 0 & 0 & 1 & 100 & 0 & 0 & \\
\hline \multirow[t]{3}{*}{5} & Pendidikan Ibu & Pendidikan Tinggi & 8 & 25 & 21 & 65,6 & 3 & 9,4 & $0,047 *$ \\
\hline & & Pendidikan & 26 & 38,2 & 27 & 39,7 & 15 & 22,1 & \\
\hline & & Rendah & & & & & & & \\
\hline \multirow[t]{2}{*}{6} & Riwayat Pemberian & $\mathrm{Ya}$ & 5 & 17,2 & 22 & 75,9 & 2 & 6,9 & $0,002 *$ \\
\hline & Asi Ekslusif & Tidak & 29 & 40,8 & 26 & 36,6 & 16 & 22,5 & \\
\hline \multirow[t]{2}{*}{7} & Riwayat Imunisasi & $\mathrm{Ya}$ & 24 & 40,7 & 22 & 37,3 & 13 & 22 & $0,036^{*}$ \\
\hline & Dasar & Tidak & 10 & 24,4 & 26 & 63,4 & 5 & 12,2 & \\
\hline
\end{tabular}

Berdasarkan tabel 2, dapat dilihat bahwa kasus pneumonia tertinggi pada anak usia 1-3 tahun adalah Penumonia Lobularis sebesar 31,7\% sedangkan kasus terkecil adalah pneumonia interstitial sebesar $24,2 \%$. Kemudian pada anak usia 45 tahun sebesar 50\% menderita Pneumonia Lobaris dan sebesar 5,9\% anak usia 45 tahun menderita Pneumonia interstitial. Dari hasil analisis diatas didapatkan $\mathrm{p}$ value sebesar 0,016, maka secara statistik dapat disimpulkan bahwa faktor usia anak mempunyai hubungan yang signifikan terhadap pneumonia karena $\mathrm{p}$ value < $\alpha(0,05)$ sehingga dapat disimpulkan bahwa terdapat hubungan yang signifikan antara usia anak dengan Pneumonia. 
Pada variabel Jenis kelamin, pada anak dengan berjenis kelamin laki-laki lebih banyak menderita Pneumonia lobularis dibandingkan pneumonia lobaris dan interstitial, yaitu sebesar sebesar $45,5 \% \%$ dan pada anak berjenis kelamin perempuan sebesar 50\% menderita pneumonia lobularis. Dari hasil analisis diatas didapatkan $\mathrm{p}$ value sebesar 0,831, maka secara statistik dapat disimpulkan bahwa faktor jenis kelamin anak tidak mempunyai hubungan yang signifikan terhadap pneumonia karena $\mathrm{p}$ value $>\alpha(0,05)$ sehingga dapat disimpulkan bahwa tidak terdapat hubungan yang signifikan antara jenis kelamin anak dengan Pneumonia.

Pada variabel Riwayat berat badan lahir, anak dengan riwayat berat badan lahir <2500 gram paling banyak menderita pneumonia lobaris, yaitu sebesar $13,4 \%$ dibandingkan pneumonia lobularis dan pneumonia interstitial. Kemudian anak dengan riwayat berat lahir 2500-4000 gram paling banyak menderita pneumonia lobularis, yaitu sebesar $46,7 \%$ dibandingkan pneumonia lobaris dan interstiti. Pada anak dengan riwayat berat lahir $>4000$ gram paling banyak menderita pneumonia lobularis sebesar $75 \%$ dibandingkan pneumonia lobaris dan interstitial. Dari hasil analisis diatas didapatkan $\mathrm{p}$ value sebesar 0,131, maka secara statistik dapat disimpulkan bahwa faktor riwayat berat badan lahir tidak mempunyai hubungan yang signifikan terhadap prestasi belajar karena $\mathrm{p}$ value $>\alpha$ $(0,05)$ sehingga dapat disimpulkan bahwa tidak terdapat hubungan yang signifikan antara riwayat berat badan lahir dengan Pneumonia.

Hasil analisis bivariat pada tabel 5.2 diatas, dapat dilihat bahwa ibu yang mempunyai pendidikan akhir adalah pendidikan tinggi sebesar 65,5\% kasus pneumonia pada anak adalah pneumonia lobularis dibandingkan pneumonia lobaris dan pneumonia interstitial. Pada ibu yang mempunyai pendidikan akhir pendidikan rendah kasus terbesar adalah pneumonia lobularis, yaitu sebesar $36,6 \%$. Dari hasil analisis diatas didapatkan p value sebesar 0,047, maka secara statistik dapat disimpulkan bahwa faktor pendidikan ibu mempunyai hubungan yang signifikan terhadap pneumonia karena $p$ value $<\alpha(0,05)$ sehingga dapat disimpulkan bahwa terdapat hubungan yang signifikan antara pendidikan ibu dengan pneumonia.

Pada variabel riwayat Asi Eklusif pada anak yang memiliki riwayat diberikan Asi Ekslusif sebesar 75,9\% anak menderita pneumonia lobularis dibandingkan pneumonia lobaris dan pneumonia interstitial sedangkan pada anak yang tidak memiliki riwayat diberikan Asi Ekslusif sebesar 40,8\% menderita pneumonia lobaris dibandingkan pneumonia lobularis dan pneumonia interstitial. Dari hasil analisis diatas didapatkan $\mathrm{p}$ value sebesar 0,002, maka secara statistik faktor riwayat pemberian Asi Ekslusif mempunyai hubungan yang signifikan terhadap pneumonia karena $\mathrm{p}$ value $<\alpha(0,05)$ sehingga dapat disimpulkan terdapat hubungan yang signifikan antara riwayat pemberian Asi Ekslusif dengan pneumonia.

Hasil analisis bivariat pada tabel 5.2 diatas, dapat dilihat bahwa anak yang memiliki riwayat imunisasi dasar lengkap sebesar 40,7\% menderita pneumonia lobaris dibandingkan pneumonia lobularis dan pneumonia interstitial sedangkan anak yang memiliki riwayat tidak diberikan imunisasi dasar lengkap sebesar $63,4 \%$ menderita pneumonia lobularis dibandingkan pneumonia lobaris dan pneumonia interstitial. Dari hasil analisis diatas didapatkan p value sebesar 0,036, 
maka secara statistik faktor riwayat imunisasi mempunyai hubungan yang signifikan terhadap pneumonia karena $\mathrm{p}<\alpha(0,05)$.

Anak balita adalah anak yang telah menginjak usia di atas satu tahun atau lebih popular dengan pengertian usia anak di bawah lima tahun (Muaris, 2006). Balita adalah istilah umum bagi anak usia 1-3 tahun (batita) dan anak prasekolah (3-5 tahun). Umur merupakan salah satu faktor resiko utama pada beberapa penyakit, hal ini disebabkan karena umur dapat memperlihatkan kondisi kesehatan seseorang. Anak- anak yang berumur 0-24 bulan lebih rentan terhadap pentakit pneumonia dibandingkan anak anak yang berumur di atas 2 tahun. Hal ini disebabkan imunitas yang belum sempurna dan lubang pernafasan yang masih relative sempit (Depkes RI. 2008).

Umur merupakan faktor risiko yang berhubungan dengan kejadian pneumonia. Resiko untuk terkena pneumonia lebih besar pada anak umur dibawah 5 tahun dibandingkan dengan yang lebih tua, hal ini dikarenakan system kekebalan anak dibawah 5 tahun belum belum sempurna (Daulaire, 2000). Berdasarkan hasil penelitian yang telah dilakukan bahwa persentase terbesar, yaitu anak pada rentang usia 1-3 tahun. Hal ini sejalan dengan hasil penelitian yang dilakukan oleh Sugihartono (2012) kejadian pneumonia pada balita berdasarkan umur paling banyak pada balita dengan umur 13-24 bulan sebesar $37 \%$. Kemudian menurut Kemenkes RI (2013) populasi yang rentan terserang pnemumonia 13-60 bulan (33,7\%). Hasil analisis statistik dapat disimpulkan terdapat hubungan yang signifikan atara usia anak dengan kejadian pneumonia.

Menurut Astuti (2010) pneumonia dipengaruhi oleh faktor-faktor seperti umur, serangan puncak pneumonia virus pada anak usia 2 dan 3 tahun. Hal ini sejalan dengan teori Menurut Misnadiarly (2008) tanda dan gejala pneumonia bergantung pada agen penyebabnya (virus atau bakteri), umur anak, daya tahan tubuh anak, luasnya area yang terkena, serta derajat kerusakan atau tingkat peradangannya. Kemudian Menurut Maryunani (2010) Faktor resiko meningkatkan insiden pneumonia dan faktor resiko yang meningkatkan angka kematian pneumonia salah satunya adalah faktor umur.

Pada variabel jenis kelamin persentase kejadian pneumonia paling banyak terjadi pada anak balita dengan jenis kelamin perempuan. Menurut Astuti (2010) pneumonia dipengaruhi oleh faktor-faktor seperti umur serangan puncak pneumonia virus pada anak usia 2 dan 3 tahun, Jenis Kelamin ; Anak laki-laki lebih sedikit terseang pneumonia daripada anak perempuan, musim dan tahun dan kepadatan penduduk. Kemudian hasil penelitian penelitian Widodo, (2007) di tasik malaya hasil menunjukan bahwa bayi dan balita yang mengalami pneumonia kemungkinan 1,524 kali lebih besar pada perempuan dibandingkan dengan anak laki-laki (Widodo, 2007).

Berdasarkan hasil uji statistik dapat disimpulkan bahwa faktor jenis kelamin anak tidak mempunyai hubungan yang signifikan terhadap pneumonia. Pneumonia merupakan infeksi akut yang menyerang jaringan paru (alveoli) yang disebabkan oleh bakteri, virus, jamur, atau terhirup udara yang tercampur (Dinkes Provinsi Kalimantan Tengah, 2014). Tidak ada hubungan dapat disebabkan oleh faktor lain, yaitu faktor ekstrinsik berupa lingkungan rumah yang terdiri dari komponen rumah yang menunjang terciptanya rumah yang sehat, 
seperti dinding, lantai, ventilasi, pencahayaan alami dan kepadatan penghuni (Depkes RI, 2009). WHO menyebutkan bahwa faktor lingkungan seperti tinggal dirumah yang penuh sesak dan pajanan terhadap orang tua yang merokok atau polusi udara dalam ruangan dapat meningkatkan kejadian pneumonia (WHO, 2006).

Berat badan lahir rendah (kurang dari 2500 gram) merupakan salah satu faktor utama yang berpengaruh terhadap kematian perinatal dan neonatal. Anakanak dengan riwayat berat badan lahir rendah akan mengalami lebih berat infeksi pada saluran pernapasan dikarenakan pembentukan zat anti kekebalan kurang sempurna sehingga lebih mudah terkena penyakit infeksi, terutama pneumonia dan sakit saluran pernapasan lainnya (Prabu, 2009). Hal ini tidak sejalan dengan hasil penelitian bahwa persentase kejadian pneumonia paling banyak terjadi pada anak balita yang memiliki riwayat berat badan lahir 2500-4000 gram.

Berdasarkan hasil analisis statistik dapat disimpulkan tidak terdapat hubungan yang signifikan antara riwayat berat badan lahir dengan kejadian pneumonia. Hasil penelitian Regina (2013) yang menyatakan bahwa tidak terdapat hubungan yang bermakna antara berat badan lahir rendah dengan kejadian pneumonia. Berdasarkan hasil penelitian ini ditemukan bahwa kejadian pneumonia paling banyak terjadi pada anak balita yang memiliki riwayat berat badan lahir 25004000 gram. Hal ini disebabkan faktor lain yang memudahkan terjadinya penularan penyakit penumonia. Menurut Maryunani (2010) faktor resiko yang meningkatkan insiden pneumonia adalah umur, gizi kurang, tidak mendapat ASI memadai, membedong anak (menyelimuti berlebihan) dan defisiensi vitamin A.

faktor resiko yang meningkatkan angka kematian pneumonia adalah umur, tingkat sosial ekonomi, gizi kurang, berat badan lahir rendah, tingkat pendidikan ibu yang rendah, tingkat jangkauan pelayanan kesehatan yang rendah, kepadatan tempat tinggal, imunisasi yang tidak memadai dan menderita penyakit kronis.

Status gizi adalah ekspresi dari keseimbangan dalam bentuk variabel-variabel tertentu. Status gizi juga merupakan akibat dari keseimbangan antara konsumsi dan penyerapan zat gizi dan penggunaan zat-zat gizi tersebut atau keadaan fisiologik akibat dari tersedianya zat gizi dalam seluruh tubuh. Berdasarkan hasil penelitian persentase terbesar kejadian pneumonia pada anak balita adalah balita yang memiliki status gizi baik. Hasil analisis statistik diperoleh tidak terdapat hubungan yang signifikan atara status gizi dengan kejadian pneumonia. Hal ini tidak sejalan dengan hasil penelitian yang dilakukan oleh Penelitian Gozali (2010) menyatakan ada hubungan yang signifikan antara status gizi dengan pneumonia di Puskesmas Gilingan Kecamatan Banjarsari Surakarta dengan prosentase terbesar anak balita dengan status gizi kurang. Kemudian penelitian yang dilakukan oleh Sugihartono (2012) ada hubungan antara status gizi dengan kejadian pneumonia. Balita dengan status gizi kurang mempunyai resiko untuk menderita pneumonia sebesar 3,121 kali lebih besar dibandingkan dengan balita yang memiliki status gizi yang baik.

Menurut Kamus Besar Bahasa Indonesia, pendidikan adalah poses pengubahan sikap dan tingkah laku seseorang dalam usaha mendewasakan manusia melalui upaya pengajaran dan pelatihan. Tingkat pendidikan orang tua 
yang rendah juga merupakan faktor resiko yang dapat meningkatkan angka kematian ISPA terutama pneumonia. Tingkat pendidikan ibu akan berpengaruh terhadap tindakan perawatan pada balita penderita pneumonia. Berdasarkan hasil penelitian bahwa persentase terbesar pendidikan ibu pada anak yang menderita pneumonia adalah ibu dengan pendidikan rendah. Hasil analisis statistik dapat disimpulkan bahwa terdapat hubungan yang signifikan antara pendidikan ibu dengan kejadian pneumonia. Hal ini sesuai dengan Menurut hasil penelitian Notosiswoyo (2003) bahwa balita yang mengalami pneumonia kemungkinan 2,04 kali lebih besar memiliki ibu yang berpendidikan rendah dibandingkan ibu yang memiliki pendidikan tinggi dan 2,4 kali lebih besar memiliki ibu yang berpengetahuan rendah dibandingkan dengan yang berpendidikan tinggi.

Tingkat pendidikan dalam keluarga khususnya ibu dapat menjadi faktor yang mempengaruhi kesehatan balita, semakin tinggi pendidikan orang tua maka pengetahuannya akan kesehatan akan lebih baik dari pada yang berpendidkan rendah. Salah satu penyebab kesakitan pada balita adalah kurangnya perhatian orang tua terhadap kesehatan anaknya (Notosiswoyo, 2003). Tingkat pendidikan ibu akan berpengaruh terhadap tindakan perawatan oleh ibu kepada anak yang menderita ISPA. Jika pengetahuan ibu untuk mengatasi pneumonia tidak tepat ketika bayi atau balita menderita pneumonia, akan mempunyai resiko meninggal karena pneumonia sebesar 4,9 kali jika dibandingkan dengan ibu yang mempunyai pengetahuan yang tepat (Kartasasmita, 2010).

Asi Eksklusif adalah Asi yang diberikan selama 6 bulan pertama kehidupan tanta makanan tambahan dan pemberian Asi dilajutkan dengan didampingi makanan pendamping Asi yang sesuai. Kolustrum mengandung zat kekebalan 1017 kali lebih banyak dari susu buatan.Pada variabel riwayat Pemberian Asi Ekslusif persentase terbesar anak balita yang mengalami pneumonia tidak memiliki riwayat pemberian Asi Ekslusif. Hasil analisis statistik dapat disimpulkan bahwa terdapat hubungan yang signifikan antara riwayat pemberian Asi Ekslusif dengan kejadian pneumonia. Hal ini sejalan dengan hasil penelitian Penelitian yang dilakukan Hartati (2011) menyimpulkan bahwa balita yang tidak mendapatkan Asi eksklusif berisiko 4,47 kali mengalami pneumonia dibanding balita yang mendapatkan ASI eksklusif.

Asi Eksklusif mengurangi tingkat kematian bayi yang disebabkan berbagai penyakit yang umum menimpa anak-anak seperti diare dan radang paru karena mengandung protein, laktoferin, imunoglobin, antibodi terhadap bakteri, virus dan jamur. Hal ini sejalan dengan penelitian yang dilakukan oleh Annah (2012) bahwa pemberian Asi Ekslusif merupakan faktor resiko terhadap kejadian pneumonoa. Balita yang mendapatkan tidak mendapatkan Asi Ekslusif secara memadai memiliki resiko 2,49 kali menderita pneumonia dibandingkan balita yang diberikan Asi Ekslusif. Kemudian Penelitian yang dilakukan Sugihartono (2012) menyimpulkan bahwa ada hubungan signifikan antara riwayat pemberian Asi ekslusif dengan kejadian pneumonia. Balita yang mengkonsumsi Asi tanpa cairan lainnya kurang dari 6 bulan beresiko 8,958 kali lebih besar dibandingkan dengan balita yang mengkonsumsi Asi tanpa cairan lainnya atau sama dengan enam bulan. 
Imunisasi merupakan salah satu cara untuk memberikan kekebalan tubuh pada bayi dan anak dengan memasukkan vaksin ke dalam tubuh agar tubuh membuat zat anti untuk mencegah terhadap penyakit tertentu (Hidayat, 2011). Cara yang terbukti efektif saat ini adalah dengan pemberian imunisasi campak dan pertusis (DPT) dengan imunisasi campak yang efektif sekitar 11\% kematian pneumonia pada balita dapat dicegah dengan imunisasi pertusis (DPT) $6 \%$ kematian pneumonia dapat dicegah (Maryunani, 2010). Berdasarkan hasil penelitian persentase terbesar kejadian pneumonia terjadi pada anak balita yang mempunyai status imunisasi tidak lengkap. Hal ini sejalan dengan hasil penelitian yang dilakukan oleh Widodo (2007) menunjukkan ada kaitan antara status imunisasi dengan kejadian pneumonia pada balita dan balita yang mengalamipneumonia kemungkinan 1,76 kali lebih besar mempunyai status imunisasi yang tidak lengkap dibandingkan yang lengkap. Kemudian hasil penelitian yang dilakukan oleh Annah (2012) menujukkan bahwa status imunisasi tidak lengkap beresiko 2,39 kali lebih besar terhadap kejadian pneumonia dibandingkan anak dengan status imunisasi yang lengkap.

\section{SIMPULAN DAN SARAN}

\section{Simpulan}

Faktor resiko yang berhubungan dengan kejadian pneumonia pada anak balita usia 1-5 tahun di Blud RSUD dr. Doris sylvanus palangka raya dapat disimpulkan bahwa terdapat hubungan yang signifikan antara usia anak, riwayat pendidikan ibu, riwayat menyusui, riwayat imunisasi dasar terhadap faktor resiko kejadian Pneumonia sedangkan pada faktor berat badan lahir, jenis keamin dan status gizi tidak ada hubungan yang signifikan terhadap faktor resiko kejadian Pneumonia.

\section{Saran}

Bagi RSUD dr. Doris sylvanus Palangka Raya dari hasil penelitian ini diharapkan dapat memberikan masukan bagi warga masyarakat khususnya ibu yang memiliki anak balita untuk mengetahui faktor penyebab penyakit pneumonia pada balita. Bagi peneliti selanjutnya diharapkan penelitian seperti ini dapat ditingkatkan baik dari jumlah sample, tempat penelitian yang berbeda seperti di puskesmas-puskemas sehingga dapat menghasilkan hasil yang lebih baik dan kasus-kasus pneumonia di kota palangka raya dapat diatasi dengan baik dan benar.

\section{DAFTAR PUSTAKA}

Astuti,\&Rahmat,2010. Asuhan Keperawatan Anak Dengan Gangguan Sistem Pernafasan. JakartaTimur : CV. TransInfo Media.

Annah, Itma dkk. 2012. Faktor Resiko Kejadian Pneumonia Anak Umur 6-59 bulan di RSUD Salewangan Maros tahun 2012. Makasar:FKM Universitas Hasanudin.

Daulaire, 2000. Ilmu Keperawatan Anak Sakit. Jakarta:CV Trans Info Media. 
Dahlan, 2007. Pneumonia : Buku Ajar Ilmu Penyakit Dalam jilid 2 edisi4, Jakarta: Fakultas Kedokteran UniversitasIndonesia.

Depkes R.I., 2008. Profil Kesehatan Indonesia. Jakarta : Kemenkes RI.

Dinkes.Prov. Kalteng, 2014. Profil Kesehatan Kalimantan Tengah 2014. Provinsi Kalimantan Tengah : Dinkes Prov. Kalimantan Tengah.

Gozali,A,2010. Hubungan antar astatus gizi dengan kejadian pneumonia dengan kalsifikasi pneumonia pada balita dipuskesmas gilingan kec.banjarsari Surakarta. Surakarta : Universitas Sebelas Maret. Surakarta.

Hartati .2011. Analisis factor resiko yang berhubungan dengan kejadian pneumonia pada anak balita di RSUDPasarebo. Jakarta : FKUI.

Hidayat, 2011. Ilmu Kesehatan Anak Untuk Kebidanan. Jakarta: Salemba Medika

Kartasasmita, Cissy B. 2010. Pneumonia Pembunuh Balita. Jakarta: Kemenkes RI.

Kemenkes. RI. 2014. Profil Kesehatan Repuplik Indonesia Tahun 2014.Jakarta : Kemenkes RI.

Misnadiarly. 2008. Penyakit Infeksi Saluran Nafas Pneumonia pada Balita, Orang dewasa, Usia Lanjut. Jakarta : Pustaka Obor

Maryunani,2010. Ilmu Kesehatan Anak Dalam Kebidanan. Jakarta:CV.TransInfo Media.

Notosiswoyo,2003. Pengetahuan, Sikap dan Perilaku Ibu Bayi/Anak Balita serta Persepsi Masyarakat dalam Kaitannya dengan Penyakit ISPA dan Pneumonia. Buletin Penelitian Kesehatan,Vol. 31, No.2.

Prabu. 2009. Faktor-faktor mempengaruhi pneumonia, Bandung : Remaja Rosdakarya

Regina R, Kriswiharsi KS, Suharyo. 2013. Faktor-faktor yang berhubungan dengan kejadian pneumonoa pada balita di wilayah kerja Puskesmas Miroto Semarang. Semarang : Universitas Dian Nuswantoro.

Sugihartono, Nurjazuli. 2012. Analisis Faktor Resiko Kejadian Pneumonia pada Balita di Wilayah Kerja Puskesmas Sidorejo Kota Pagar Alam. Jurnal Kesehatan Lingkungan Indonesia vol 11 No1.

Widodo,2006.Faktor yang berhubungan dengan kejadian pneumonia. Surakarta

WHO, 2003, Penanganan ISPA pada Anak di Rumah Sakit Kecil Negara Berkembang. Jakarta : EGC.

WHO. 2010. Pneumonia http://www.who.int/mediacentre/. 